IOLRNAL OF MENTAI, SCIENCE, IANIARY, 19,32.

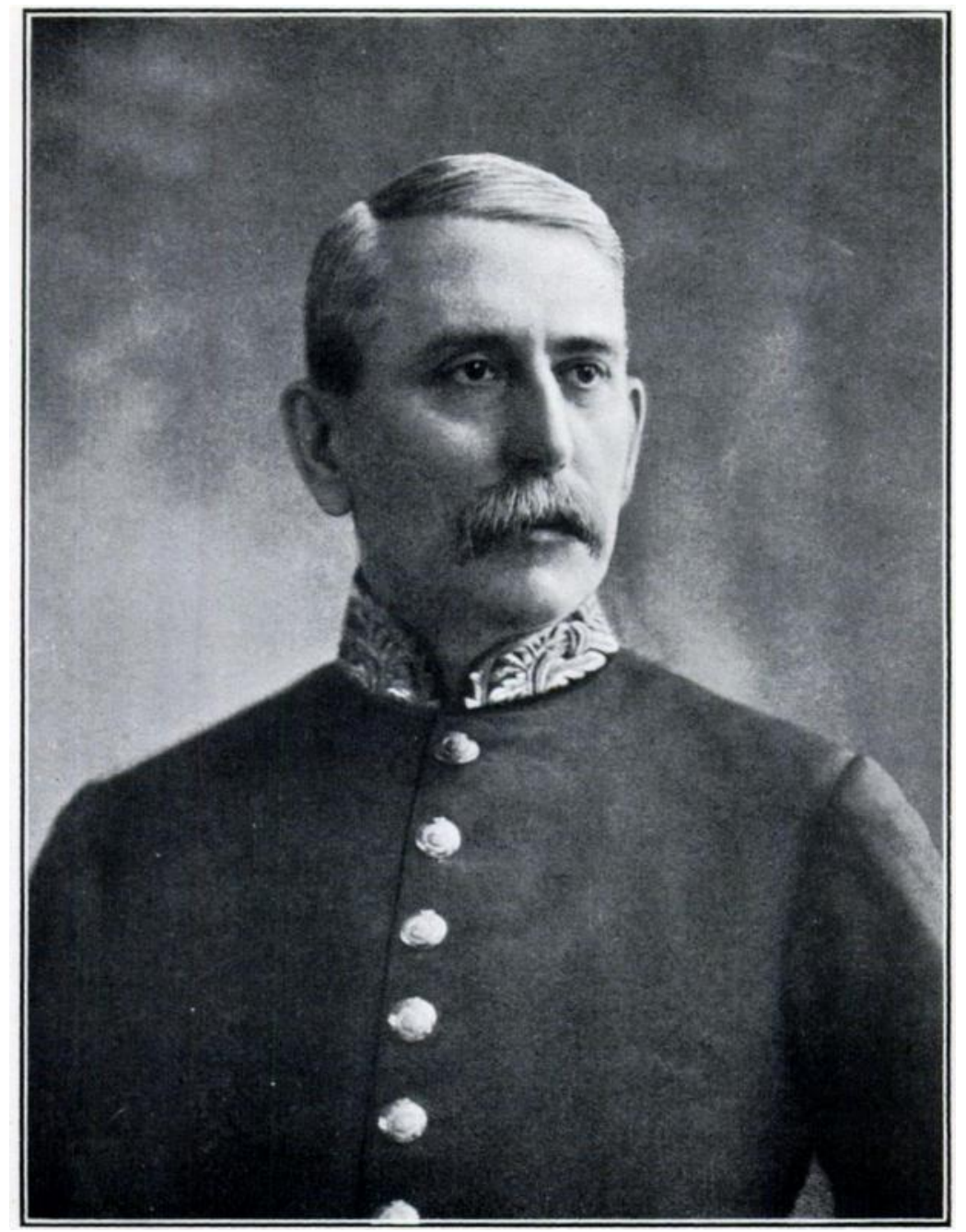

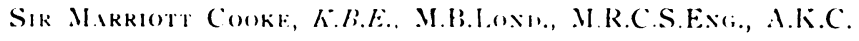

Born February 4, 1852 .

Died October 17,1931 .
Ordinary Nember, 1878 .

Honorary Nember, 1918. 


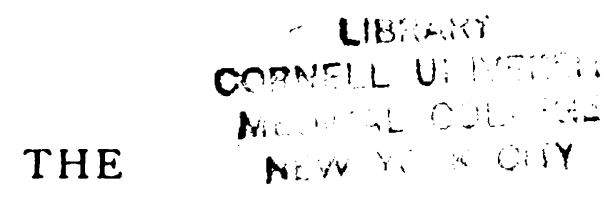

JOURNAL OF MENTAL SCIENCE

[Published by Authority of the Royal Medico-PsychologiAPR $\approx \mathrm{s} 19:$ Association.]

No. $320\left[\begin{array}{c}\mathrm{NRW} \text { sRriks } \\ \text { No. 284. }\end{array}\right] \quad$ JANUARY, 1932. VOI. LXXVIII

\section{SIR MARRIOTT COOKE, K.B.E., M.B.LOND., M.R.C.S.ENG., A.K.C.}

Sir MARriotr Cooke, whose death in his eightieth year took place on October I7, I93 I, constituted a link between Mid-Victorian psychiatry-if it is permissible to claim such an abstraction-and the modern outlook for which the arrival in our time of the Mental Treatment Act stands.

The elder of the two children of the late Henry Edward Cooke, of Harrow-on-the-Hill, Edward Marriott Cooke was born in 1852 . Educated privately at Southampton and at Cholmeley's School, Highgate, he matriculated in 1869 at the University of London, entered on September 27 in the same year upon his medical curriculum at King's College, and completed his clinical studies at King's College Hospital.

During his undergraduate years he resided in college, the benefit of which he always extolled in later life. He sang in the College Chapel choir, and it was doubtless the training that he received there, coupled with a rich baritone voice, that did much to develop his love of music and to render his singing so acceptable. He also regularly attended the College lectures on Divinity - a fact which is consonant with, if perchance it does not partly explain, the never wavering and deeply religious side of his character. He was elected an A.K.C. in 1875. Before leaving college he held the post of Assistant Demonstrator in Anatomy.

Cooke did not enter the medical profession with any preconceived idea of devoting himself to psychiatry; nor is it known to what extent he was interested or impressed by the lectures delivered in Psychological Medicine at the College or by the demonstrations given at Colney Hatch Mental Hospital. Indeed, so soon as his 
thoughts began to direct themselves as to the line which he would like to pursue, it was towards obstetrics and gynæcology that he felt attracted. Upon his own testimony it is, however, certain that when he sought and obtained the post of Junior (second) Assistant Medical Officer at the Worcester County and City Mental Hospital at Powick, it was avowedly with the object, while gaining useful experience, of doing some hard reading and of proceeding to some of the higher professional qualifications. He had (May, 1873) already passed his Primary F.R.C.S. examination-no less a feat in those days than it is still regarded-and, having obtained the membership of the College of Surgeons in April, I874, he was due to sit for his final M.B. examination; this he passed in 1877 . In those days there was a separate examination for the degree of Bachelor in Surgery ; but neither to this degree nor to any further professional examination did Cooke ever proceed. In point of fact Cooke had no particular academic leanings. Professional or scientific reading was not the relaxation to him which it is to some persons, and his absorption of facts of that type was apt to be slow and deliberate; but, once absorbed, they were tenaciously held. and their underlying principles unswervingly upheld. Not that his practical rather than scientific bent of mind in the least implied any failure to keep in touch with medical progress. His stern sense of duty - and no one has ever maintained a sterner one-would have forbidden any such failure. On the contrary, he was a regular reader of medical journals, and later on in professional life, although he did not himself prosecute laboratory or other allied work, he gave full scope and encouragement to his junior colleagues, and felt a right pride in any attainments they made in those directions. It was probably from his bias towards the administrative side of his work that may be explained the fact that, so far as contributions to medical literature were concerned, writing of an academic or purely medical nature was always an effort to him; and that, so far as can be recalled, his only contribution to any medical journal was a paper which he read at the Quarterly Meeting of the Royal Medico-Psychological Association held at Powick in February, 1895." Entitled "A Review of the Last Twenty Years at the Worcester County and City Lunatic Asylum, with some Conclusions derived therefrom," it was a thoughtful, practical and valuable address, to which further reference will be made later on in these remarks. Four years previously, upon his election as President of the Worcester and Hereford Branch of the British

* See Journ. Ment. Sci,., July, I895, xli, pp. 387-402. 
Medical Association, and at their Annual Meeting held* in the Worcester Infirmary, he delivered an address on "Some Points Connected with the Causation of Mental Disease." It is much to be regretted that his remarks on that occasion do not seem to have been published. On the other hand, his official writings, whether reports to visiting committees of mental hospitals-and it is noteworthy how early in his career he was called upon to furnish such reports-or entries, reports and minutes arising out of his work as a Commissioner, are all remarkable for their lucidity, logical coherence, nicety in choice of words and phrasing, for their exact adherence to fact, with a total absence of anything savouring of exaggeration, and for the feeling always conveyed in them that the matter in question had been the subject of careful deliberation. Nor, when some recommendation seemed called for, did they ever fail to make quite clear what opinion he had formed, and what was the advice which he tendered. These are great qualities, and such reliability is of the utmost value. Moreover, once this position had been attained, as all who had the privilege of working with Sir Marriott Cooke would testify, there would be no receding from it ; come what may, he could be counted upon to hold his ground. Between such an attitude and that of mere stubbornness there is, of course, a great difference: the former is strength, the latter is weakness of character.

Not unnatural is the reader's possible thought that such references to this part of Cooke's character would be more fitting if made in relation to his more matured years; but, in point of fact, these traits were conspicuous even in the early years of his official life.

When Cooke arrived to take up his duties at Powick, the tongue of good report had already been heard in his favour. In those days, for a man to be able to place "M.B. Univ. Lond." after his name possessed something of a glamour; and it was something out of the common for a young doctor, with the Primary Fellowship behind him and on the eve of taking his M.B.London, to be seeking the junior post in a county asylum so 1 urally situated as Powick. Not that there was at this period any lack of men of the highest distinction in the British psychiatric field, as a glance at the names of those at work in it at the date, 1878 , when Cooke became a member of the Medico-Psychological Association, is sufficient to demonstrate. Thus, our doyen, Dr. (now Sir James) Crichton-Browne, was its President, and as Editors of the Association's Journal were Maudsley and Clouston, the former of

- On June 26, 1891. See Brit. Med. Journ., July 4, 1891, p. 38. 
whom in the following year was succeeded by Hack Tuke and Savage.

On joining at Powick, Cooke found, as Medical Superintendent, Dr. James Sherlock, a man of high medical attainments and of peculiarly suave, courtly and attractive manner. $\mathrm{He}$ it was who, away back in 1858 , was largely instrumental in securing as President of the Medico-Psychological Association for the ensuing year Sir Charles Hastings, of Worcester, ${ }^{*}$ whose Foundation of the British Medical Association is, in part, to be celebrated this year by a pilgrimage to that city. Sherlock was, however, past the zenith of his powers : though not yet fifty years of age, failure in health was being hastened by an unwise reluctance to leave the confines of his hospital-a habit which, if not fought against, is apt to grow upon those occupying residential posts in institutions.

Very swiftly, Cooke's interest was roused in the treatment of mental disorders, in the welfare of the insane, and the need of vigilance for their protection-an interest that deepened and throughout his life never flagged. He not less swiftly recognized, however, that there was room for improvements, of which one of the earliest he had in mind was the better supervision of the patients by night. The Hospital at Powick contained, at the time he joined its staff, 313 male and 356 female patients; and there was not so much as one attendant or nurse on continuous duty throughout the night; whereas, when he left in 1898 to join the Lunacy Commission, there were six on the male side for 475 patients and nine night nurses for 620 women patients: that is, a proportion of one night nurse to every 73 patients, which, if it is not quite as liberal as that which obtains to-day, is not far short of it.

Shortly after Cooke had become the senior of the two assistants and was in the position of Deputy Superintendent, and after he had decided to devote himself to mental hospital work, serious illness befell his Chief. Not only did he find himself called upon to act as Superintendent for a period of several months, but, in relation

* The acceptance by Sir Charles Hastings of this Presidentship was the first occasion, since the Foundation of the Association in 1841 , that its Chair had been occupied by some one not identified with the treatment of nervous and mental disorders. A similar departure was made in 1869 when Thomas Laycock, Professor of Medicine at Edinburgh, was President; and again, but for the last time, when in 1882 Sir William Gairdner, of Glasgow, occupied the chair for that year. It is true that, owing to his predilection for the study of neurological and mental disorders, it used to be said, and sometimes complained of, that Laycock's lectures were a course rather of psychological medicine than of the practice of physic. Is there not, however, something to be said for the wisdom of electing, from time to time, some one as President who, while sympathetic towards the special aims and needs of psychiatry, is himself identified essentially with general medicine ? 
to consideration which was being given to the best means of providing further accommodation, it also devolved upon him to visit, on behalf of the Committee, a number of mental hospitals in order to collect information, and to frame a report for their con. sideration. Despite his short experience, Cooke acquitted himself well ; he won high credit both for his management of the institution and for his grip of its future necessities. His outstanding capacity was acknowledged, added to which he possessed good looks and a commanding presence. Erect and of somewhat military bearing and carriage, he looked more than his real height: dark, nearly black hair, healthy, rather swarthy complexion, strongly marked eyebrows, piercingly dark eyes which could, and did at times, give a flash which was a warning that it might ill-betide one who would venture on liberties with him, and an attractive rich voice, he was obviously one upon whom responsibility would sit well. It was well known, too, that he was exceptionally well qualified professionally. Though it is fifty-three years ago and the writer was scarcely eight years old, memory recalls him vividly, as well as the glamour that somehow seemed to surround him and his doings.

Small wonder then, although such quick and early promotion excited some comment at the time, that when in 1877 the post of Superintendent at the Wilts County Mental Hospital, Devizes, became vacant, Cooke was appointed from among no less than 45 candidates. It was not destined, however, to be very long the sphere of his activities; and from the records during the comparatively short time, less than four years, that it was his home, the only items of interest are: the erection, commenced in April of 1878 , of a new unit for female patients upon plans settled apparently before Cooke's arrival; and, arising out of circumstances connected with the death of a patient during that year and discussion with the Commissioners in Lunacy upon the subject, the setting apart of a ward in both the male and female divisions of the Hospital for sick and infirm cases, these wards being placed by night as well as by day under the charge of competent nurses. Another forward step-not so petty as perhaps those unfamiliar with mental hospital difficulties might think-was the removal of the cleansing of the foul linen from the general washhouse to a separate building.

Brief though Cooke's term of office was at Devizes, it was a momentous period in his life: for it was while here that, in February, 1879, he married Mary Anne Henrietta Cecil, fourth daughter of Sir George Brooke-Pechell, fifth Baronet, of Alton 
House in Hampshire. Something more must be said of this gracious and talented lady when referring to the period of Cooke's recall to Powick.

On May 13, I88I, Dr. Sherlock died suddenly at the early age of 53, and thus the post of-to give it its exact title-Medical Officer and Superintendent at Powick Mental Hospital became vacant. Some indication of the importance attached to the post in the mind of the public and of the esteem in which its recent occupant for twenty-seven years was held may be gathered from the fact that, besides a somewhat remarkable lectern erected to his memory in the Hospital's Church, a granite obelisk, the cost of which was defrayed by public subscription, was placed over his grave in the parish churchyard of St. Peter's, Powick. The contest for the post was keen, but finally Cooke was unanimously appointed.

For the ensuing seventeen years the whole of Cooke's energies were devoted to the administration of his Hospital and to the welfare of its patients and staff. This was the period when the self-sufficing character of mental hospitals was at its height. The treatment of mental disorder anywhere but in them, or in places authorized by the Lunacy Acts, was not only illegal, but its impropriety, speaking generally, was not questioned. There was hardly any thought of the out-patient treatment of mental illness, * still less of any official link with general hospitals; and, save to meet the requirements of some surgical case of special difficulty, the resident medical and nursing staff was expected to be allsufficient for the needs of these hospitals. As we know, although in the early years of the present century doubts began to be felt as to the wisdom of such isolation, and broader conceptions were beginning to germinate, it took the war and the working of the asylum war-hospital scheme to break down these traditions. In their light there is, however, not the slightest doubt but that the all-round reputation of the Worcester County and City Mental Hospital was deservedly high.

Throughout these seventeen years at Powick, Cooke was busily engaged in effecting improvements in his Hospital. Its accommodation rose from 770 beds at the time he rejoined as Superintendent in $\mathrm{I} 88 \mathrm{I}$ to $\mathrm{I}, \mathrm{I} 100$ at the time of his appointment, in 1898 ,

* It is of some interest to note that, in the discussion on the paper which Sir Marriott Cooke read at Worcester in February, 1925, Dr. Conolly Norman spoke in praise of what he termed the "externe" treatment of the insane, with special reference to its practice at Wakefield Mental Hospital and at St. Thomas's Hospital in London. He foresaw the great advantage which an extension of its use would prove to be. (See Journ. Ment. Sci., July, 1895, xli, p. 403.) 
as Commissioner in Lunacy. This enlargement was designed to relieve the main building of its idiots, imbeciles, demented epileptics and other demented patients of defective habits, and thus to keep separate from such cases the "acute, intelligent and curable" patients. It was effected by the erection of an annexe connected by a long corridor with the main building, and in many ways it has served its purpose, though it is certain that, had its erection taken place within the last ten or fifteen years, Cooke would have advised buildings of a different kind, and would have preferred to leave this unfavourable type of patient in the older wards.

That his ideas were tending in the direction just mentioned may be gathered from his conclusions based upon a twenty years' review to which allusion already has been made. He there stated that, although too large, the best feature in his Hospital was the two wards for "well-disposed working patients and convalescents" of each sex, detached from the main building. It is from this address that Cooke's views can best be gathered. Note may be taken of the following points: again may be seen his emphasis on the value of adequate night-nursing; also, by his constant efforts to improve the sanitary arrangements and water supply, the importance he attached to these matters and the satisfaction with which he saw the Hospital's death-rate reduced in 1891 to $6.2 \%$; and the evidently equal importance he attached to an adequate dietary, with his preference for liberaiity in milk rather than meat. Contrary to many of his contemporaries at that time, he expressed approval of the recent statutory requirement, under Section 48 of the 1890 Lunacy Act, of the recertification of patients at specified periods. He evidently doubted whether workhouse care was really economical even for "harmless imbeciles and dements," and regarded it as "positively harmful " for recent cases. He strongly advocated, and did much to promote, fixed rather than optional pensions ; and, always a firm believer in the provision of an adequate number of good cottages on the estate for married male members of the staff, he had the satisfaction of seeing a considerable number erected during his superintendentship. With regard to the teaching and training of the nursing staff, his Hospital seems in his time to have relied upon the giving of its certificate rather than sending candidates up for outside examinations. He hailed with warm praise the then recent decision of the London County Council to appoint a central and whole-time pathologist for their mental

- Dr. (afterwards Sir Frederick W.) Mott, F.R.S., F.R.C.P., was appointed in 1895, a few months after the delivery of this address by Sir Marriott Cooke. 
hospitals, and expressed the hope that it would lead to some similar groupings in the provinces.

He had a strong conviction in the value of occupation, and claimed that fully $70 \%$ of his patients were usefully employed in one way or another. Upon amenities in the wards and the creature comforts of the patients he greatly insisted, maintaining, for instance, for the sake of its general comfort, an open coal fire in every ward, notwithstanding the extension to them of heating by steam radiators.

It was often Cooke's lament, later on as a Commissioner, that in these matters of occupation, of amenities and comforts in the wards, of amusements, of the maintenance of a good band and a well-trained choir, many mental hospitals are not nearly so enthusiastic as they once were; and he liked to encourage a determined effort to surmount difficulties in these matters which, he realized, had grown up during and since the war.

Hard worker as Cooke was, and insistent upon his subordinates doing their full share, he never lost sight of the importance of physical exercise or of social claims, either for himself or other members of the staff. Quite probably he had in mind the selfneglect and premature death of his predecessor. It was, for example, his habit, partly for exercise and partly to keep in touch with what was going on, to mount his horse after breakfast and take an early ride round the farms belonging to the Hospital before going down to his office. The grounds extended to over 500 acres; and nothing, he used to say, made him feel so fit for a hard day's work as this ride.

Here perhaps is the most convenient place to make some further reference to Lady Cooke. From the day of their marriage in 1879 to that of her death, which took place suddenly on November 9 , 1927, of no wife has the word "helpmate" ever been more fittingly used. One of a large family-six brothers and six sisters-she possessed a charm and a sympathy with human foibles and failings that possibly is acquired in no other of life's schools. As a result, she was able, in contact with persons of a younger generation, to correct many a roughness and angularity, and in a manner that disarmed and left gratitude instead of a sting. Her influence upon the Hospital's staff and upon many a one in the circle of her friendship was great. Of her husband's position and work she was immensely proud; and to the vein of irritability and martinet tendency which lay in his nature, she was a most affectionate and effective antidote. An accomplished pianist and singer, she 
responded to her husband's fondness of music, and was always ready to give her services, whether for the Hospital, or for the musical and philharmonic societies of which there were several in the neighbourhood. Towards ill-health, from which she for many years suffered, she was extraordinarily brave; and never allowed it to interfere with her many duties as hostess or with her accompanying her husband into society. Later on she took her husband's duties as a Commissioner very seriously, and in many a thoughtful way tried to lessen the stress entailed by much travelling, especially in the winter. To take a leap in this narrative, it is indeed no wonder how great a blow to her husband was her death: not indeed softened-as his friends could not help observing-by the four years which separated his death from hers.

At the end of sixteen years as Superintendent at Powick, the Committee of Visitors, entirely upon their own initiative, decided to add another $£ 300$ a year to his salary. Not only so, but they passed a resolution, and sent it to the Press, in which they added a rider to the effect that they wished thus to testify that, in their opinion, they possessed a Superintendent "second to none in the Kingdom." As this signal mark of favour was publicly announced, and when the membership of the Committee at that date is borne in mind, it cannot have occasioned surprise when the post of Commissioner in Lunacy vacant by the death of Dr. J. A. Wallis was offered to Dr. Cooke.

It is less easy to supply details as to Cooke's work and views as a Commissioner than as a Superintendent, because so much of it all, in his case, is innominate, and merged in the corporate activities of the Board of Control. Cooke was not an innovator; he preferred to abide by the well-tried measures and arrangements upon which his matured experience had taught him to rely. He was, however, immediately interested in any new suggestion which might advance the treatment of mental disorder; and, if often enough benevolently sceptical as to its ultimate value, he was always ready to encourage its trial. He frequently lamented how little was done in the way of preventing mental disorder in the light of confident statements as to certain of its causes; he had in mind such factors as alcohol, syphilis and infective foci. He read every letter addressed to him from patients; and at his visits of inspection, he always insisted that to see the patients, and to leave them satisfied at having had an opportunity to ventilate grievances, was a cardinal matter. Rigorous and carcful in looking into details, 
he was held, especially in his early years as a Commissioner, somewhat in awe; no doubt his appearance, as already described, and some sternness or austerity of manner tended to engender this feeling; but no one who ever had occasion to unburden themselves to him in a difficulty failed to find in him a most kindly nature, and a wisdom that seemed at once to remove at least half the difficulty. In his later years, with some stoop in his shoulders, and especially after the War and the many contacts he made in other spheres of official work, there was a mellowness which suggested that he found it easier to rest on the assumption that folks were doing their best than to criticize their efforts.

During the war Cooke was especially concerned in the Board's initiation of "The Asylum War-Hospital Scheme," to carry which into effect and, with the help of the local authorities, to develop it, his whole-time services, along with those of one of his colleagues, were lent to the War Office from March, 1915, to November, 1916. Under this scheme, twenty-four well-equipped war hospitals providing over $3 \mathrm{I}, 000$ beds were arranged; and there were treated in these hospitals some 480,000 cases-that is, one-sixth of the total number of sick and wounded soldiers from all fronts. For a man aged 63, Cooke's enthusiasm and energy in connection with this scheme were remarkable, as was his resourcefulness and fertility of suggestion. Naturally, the officers commanding bore the brunt and deserve a lion's share of credit; but many were the advantages which the soldiers reaped that were the fruit of suggestions by Cooke. Details of the scheme, of its working and of its closing down are to be found in the Report of May I5, 1920, entitled, "History of Asylum War-Hospitals in England and Wales," which, in conjunction with his colleague, he made to the Secretary of State. For a while he also acted with his colleague as Medical Referee at Scotland Yard in doubtful internment cases.

From November, 1916, to July, 1918, Cooke acted as Chairman of the Board of Control-that is, during the time the then Chairman, Sir William Byrne, K.C.V.O., C.B., served as Under-Secretary to the Lord Lieutenant of Ireland. It was in 1918 that, for his war services, as well as for forty-three years spent in the service of the public and as a Commissioner, he was created a K.B.E.- a dignity which all those who knew his work felt that he richly deserved.

Painstaking and almost meticulously methodical, and despite a really excellent memory, Cooke cultivated a habit of jotting down on scraps of paper memoranda both of items to be attended to during the day and of points not to be forgotten at meetings of 
the Board or in Committee; often enough, too, there would be a brief "N.B." as to alternative lines of thought or argument. Besides his other capacities, such habits made his presence of great force. It is not too much to say that, throughout the thirty-two years he was a member of the Board, great weight and reliance were invariably extended to his opinions, and that, in matters relating to public mental hospitals, his views generally were accepted without question.

On his resignation in August, 1921, Sir Marriott Cooke was appointed an Honorary Commissioner. This position he continued to hold and regularly to attend meetings of the Board, as well as to pay some occasional official visits, up to the coming into operation, on January I, I93I, of the Mental Treatment Act, under which the appointment of honorary members of the Board ceased. On the 26th of that month his colleagues entertained him to dinner, in order to mark both the affectionate esteem in which they had held him, and their sense of his devotion to the cause of those suffering from mental disorder during his long term of public service, which had extended to fifty-six years.

Sir Marriott and Lady Cooke had no children, and his only surviving relative is his nephew, Mr. George G. Briggs. Following a service in St. Jude's Church, Courtfield Gardens, on October 20, the remains of Sir Marriott were laid to rest beside the grave of his wife in Brompton Cemctery.

Hubert Bond. 